\title{
EFEKTIVITAS EKSTRAK DAUN SAMBILOTO (Andrographis paniculata) BAGI PENGENDALIAN PENYAKIT KOI HERPES VIRUS (KHV) PADA IKAN MAS (Cyprinus carpio)
}

\author{
Taukhid"), Ida Suharni ${ }^{* * t}$, dan Hambali Supriyadi ${ }^{* * *}$
}

\begin{abstract}
ABSTRAK
Riset ini bertujuan untuk mengetahui efektivitas ekstrak daun sambiloto (Andrographis paniculata) bagi pengendalian penyakit koi herpes virus (KHV) pada ikan mas (Cyprinus carpio). Daun sambiloto dalam bentuk sediaan kering diekstrak melalui perebusan. Pengujian efektivitas antimikrobial dilakukan secara in vitro terhadap bakteri Aeromonas hydrophila sebagai model. Hewan uji yang digunakan adalah ikan mas ukuran 10--15 g/ekor yang secara definitif terinfeksi KHV. Konsentrasi ekstrak daun sambiloto yang diterapkan adalah A $(100 \mathrm{mg} / \mathrm{L}), B(200 \mathrm{mg} / \mathrm{L}), \mathrm{C}(300 \mathrm{mg} / \mathrm{L}), \mathrm{D}(400$ $\mathrm{mg} / \mathrm{L}$ ), dan E (tanpa sambiloto sebagai kontrol). Perlakuan dilakukan menggunakan cara perendaman dengan waktu eksposur tidak terbatas. Deteksi KHV pada masingmasing kelompok perlakuan dilakukan setiap minggu dan riset berlangsung selama 3 minggu. Rataan sintasan ikan uji pada kelompok perlakuan adalah $\mathrm{A}, \mathrm{B}, \mathrm{C}, \mathrm{D}$, dan $\mathrm{E}$ masing-masing adalah $11,12 \%, 16,12 \%, 31,67 \%, 42,22 \%$, dan $12,78 \%$.
\end{abstract}

ABSTRACT: The efficacy of sambiloto leaf extract, Andrographis paniculata to control of koi herpes virus (KHV) on common carp, Cyprinus carpio. By: Taukhid, Ida Suharni, and Hambali Supriyadi

The research with the aim to know an efficacy of sambiloto leaf, Andrographis paniculata to control of koi herpesvirus (KHV) on common carp has been conducted in laboratory level. Sambiloto leaf in dry form was extracted by boiling technique. In vitro test of anti microbial properties of sambiloto extract was done against Aeromonas hydrophila isolate as a model. Result of the above research was used as reference for further research. Common carp with the size of 10--15 g/fish, and positively infected by KHV were used as fish test. The treatments applied were A (100 $\mathrm{mg} / \mathrm{L}), B(200 \mathrm{mg} / \mathrm{L}), C(300 \mathrm{mg} / \mathrm{L}), D(400 \mathrm{mg} / \mathrm{L})$, and $E$ (without sambiloto extract as a control).Treatment conducted by immersion for indefinite time of exposure. KHV detection of each treatment was done weekly, and research was lasting for 3 weeks. Results of the research showed that mean percentages of survival rate are: $A(11.12 \%)$, $B(16.12 \%), C(31.67 \%), D(42.22 \%)$, and $E(12.78 \%)$.

KEYWORDS: Efficacy, Andrographis paniculata leaf extract, koi herpes virus, common carp

\section{PENDAHULUAN}

Ikan mas merupakan salah satu komoditas ikan pangan yang strategis, pemasok protein hewani bagi masyarakat Indonesia. Anonim
(2004) melaporkan bahwa produksi perikanan air tawar didominasi oleh jenis ikan mas, yaitu sebesar 46,5\%. Namun sejak pertengahan 2002, produksi ikan mas merosot tajam akibat wabah penyakit koi herpes virus (KHV).

\footnotetext{
") Balai Riset Perikanan Budidaya Air Tawar, Bogor

**) Fakultas IImu Kelautan dan Perikanan, Universitas Padjadjaran, Bandung

***) Pusat Riset Perikanan Budidaya, Jakarta
} 
KHV merupakan patogen penyebab kematian masal pada ikan mas dan koi, dan nama tersebut pertama kali diajukan oleh Hedrick et al. (2000). An Emergency Disease Control Task Force on a Serious Disease of Koi and Common Carps in Indonesia yang dikoordinir oleh NACA pada Juni 2002, menyebut penyakit tersebut sebagai Mass Mortality of Koi and Common Carp (MMKCC). Kemudian Ronen et al. (2003) meragukan bahwa penyakit tersebut disebabkan oleh infeksi virus herpes, sehingga ditawarkan nama baru yaitu Carp Nepritis and Gill Necrosis Virus (CNGV). Namun dari ketiga nama yang diperdebatkan tersebut, satu hal yang sangat jelas yaitu penyebab utama dan akibat yang ditimbulkannya adalah sama; dan penyakit tersebut di Indonesia lebih populer dengan nama Koi Herpes Virus (KHV).

Kerugian ekonomi yang diakibatkan oleh penyakit tersebut sejak kehadirannya di Indonesia (Maret 2002) hingga akhir tahun 2005 diperkirakan mencapai lebih dari 150 milyar rupiah. Berbagai upaya telah dilakukan oleh stakeholders seperti pembentukan posko penanggulangan wabah, workshop dan seminar, sarasehan, penyaluran bantuan, dan lainlain. Termasuk pemberlakuan aturan khusus terhadap ikan mas dan koi yang akan dikirim dari Pulau Jawa ke pulau lainnya yang diatur dengan Surat Keputusan Menteri Departemen Kelautan dan Perikanan No. 28/Men/2002 dan No. 40/Men/2002; serta penetapan Wilayah Sumatera sebagai wilayah karantina terhadap penyakit tersebut melalui Kepmen No.55/ Men/2004.

Hingga kini belum tersedia teknologi pengendalian KHV yang memiliki tingkat keberhasilan dan kesesuaian yang tinggi untuk berbagai sistem budi daya ikan mas dan koi. Namun berdasarkan pengalaman selama ini, nampaknya strategi yang paling mungkin untuk pengendalian penyakit tersebut antara lain melalui pendekatan ekologis dan biologis.

Penggunaan obat/antibiotik yang dilakukan pembudi daya ikan mas untuk pengendalian penyakit KHV hanyalah salah satu upaya untuk menekan infeksi sekunder oleh patogen lain seperti bakteri, jamur atau parasit, namun tidak berperan untuk mengobati infeksi KHV. Meskipun upaya pengobatan tidak banyak menolong kesembuhan pada populasi ikan yang sudah terinfeksi hingga level infeksi berat, namun terhadap populasi ikan yang belum memperlihatkan gejala klinis dan kematian yang serius, upaya pengendalian melalui perbaikan lingkungan, pakan yang disuplementasi dengan imunostimulan dan penggunaan bahan kimia/antibiotik umumnya dapat mengurangi risiko kematian.

Penggunaan bahan-bahan alami (herbal therapy) seperti ekstrak daun sambiloto, daun pepaya, bawang putih, buah mengkudu (pace), cacahan buah maja, dan lain-lain, sudah banyak dilakukan oleh pembudi daya untuk melawan KHV. Keberhasilan yang diperoleh cukup variatif dan beberapa pembudi daya merasa puas dengan upaya tersebut. Nampaknya herbal therapy harus menjadi kecenderungan bagi upaya pengendalian penyakit ikan di masa mendatang, oleh karena itu perlu upaya: (1) inventarisasi herba yang berpotensi sebagai anti mikrobial (parasit, jamur, bakteri dan virus), (2) bahan aktif yang terkandung dalam herba tersebut (farmakologi), serta manfaatnya (farmakoterapi), (3) kadar bahan aktif dan teknik ekstraksinya, serta (4) dosis efektif, baik secara in vitro maupun in vivo.

Sambiloto (Andrographis paniculada), Ness merupakan salah satu bahan obat tradisional yang sudah dikenal sejak dahulu kala, baik oleh orang Indonesia maupun bangsa-bangsa lain di dunia. Jenis tanaman ini banyak dijumpai di wilayah Indonesia (dengan nama yang berbeda-beda di tiap daerah), Malaysia, Philippines, Sri Lanka, dan India (Prapanza \& Marianto, 2003). Bahan aktif yang terkandung di dalam daun, batang, bunga, dan akar sambiloto antara lain: andrographolid, alkane, keton, aldehid, asam kersik, kalium, kalsium, natrium, minyak asiri, laktone (neoandrographolid, andrographolid, deoksiandrographolid, 14-deoksi-11, dan 12-didehidroandrographolid), serta flavonoid.

Riset ini bertujuan untuk mengetahui efektivitas ekstrak daun sambiloto bagi upaya pengendalian penyakit KHV pada ikan mas.

\section{BAHAN DAN METODE}

\section{Uji Potensi Antimikrobial dan Toksisitas Bahan Terhadap Hewan Uji}

Hasil uji pendahuluan diketahui bahwa hasil ekstraksi asal 3 (tiga) bentuk sediaan sambiloto: daun basah, daun kering (simplisia), dan daun yang telah dihaluskan (bubuk); hasil terbaik diperoleh dari bentuk sediaan kering dan bubuk melalui teknik perebusan. Berdasarkan hasil tersebut, maka untuk tujuan efisiensi dan aplikasi, bentuk sediaan 
sambiloto yang selanjutnya digunakan pada kegiatan riset ini berbentuk daun kering. Sebanyak $100 \mathrm{~g}$ daun sambiloto direbus dengan menggunakan kuali (bejana yang terbuat dari tanah) dalam $1.000 \mathrm{~mL}$ air hingga mendidih selama beberapa menit. Air yang mengandung ekstraksi tersebut digunakan sebagai larutan baku (stock solution) yang memiliki konsentrasi 10\% atau $100.000 \mathrm{mg} / \mathrm{L}$.

Pengujian potensi anti mikrobial ekstrak daun sambiloto secara in vitro terhadap esktrak daun sambiloto secara bertingkat pada dosis 100, 300, 500, 1.000, dan $3.000 \mathrm{mg} / \mathrm{L}$ terhadap isolat bakteri Aeromonas hydrophila (koleksi Laboratorium Riset Kesehatan Ikan). Proses pengujian potensi anti mikrobial dilakukan dengan metode difusi agar. Pelekatan bahan aktif asal ekstrak sambiloto pada paper disc berdiameter standar dilakukan melalui perendaman selama 60 menit kedalam masing-masing konsentrasi larutan yang telah ditentukan, untuk selanjutnya ditempelkan pada biakan bakteri model. Hasil uji in vitro digunakan sebagai referensi pada pengujian secara in vivo.

Uji toksisitas ekstrak daun sambiloto terhadap ikan uji dilakukan dengan metode standar pengujian bioassay pada dosis 1.000, $2.000,3.000,4.000$, dan $5.000 \mathrm{mg} / \mathrm{L}$ selama 72 jam untuk mendapatkan nilai $\mathrm{LC}_{50}$. Sebanyak 30 ekor ikan uji direndam dalam masing-masing larutan yang telah ditentukan. Pengamatan toksisitas bahan terhadap ikan uji dilakukan pada jam ke-1, 2, 4, 8, 24, 48, dan 72 .

\section{Ikan Uji}

Ikan yang digunakan sebagai ikan uji adalah ikan mas ukuran antara 10-15 g/ekor dengan rataan 14,5 g/ekor yang diperoleh dari petani ikan di sekitar Bogor dan Sukabumi. Populasi ikan yang hendak digunakan pada percobaan ini, terlebih dahulu diinfeksi secara buatan terhadap KHV melalui proses kohabitasi terkontrol selama tiga hari pada kondisi lingkungan yang sesuai untuk replikasi virus KHV. Kepastian bahwa populasi ikan tersebut positif terinfeksi KHV didasarkan pada batasan "definisi kasus KHV" (Taukhid et al., 2005), serta dikonfirmasi secara laboratoris melalui uji polymerase chain reaction (PCR) menurut Gray et al. (2002). Kepadatan ikan uji per wadah ditentukan sebanyak 1 ekor/L. Pakan yang diberikan selama percobaan berupa pakan komersial, dengan frekuensi pemberian sebanyak dua kali sehari secara ad libitum.

\section{Wadah dan Rancangan Percobaan}

Wadah percobaan berupa boks plastik volume $80 \mathrm{~L}$ yang diisi air sebanyak $60 \mathrm{~L}$. Air pemeliharan dilengkapi dengan aerasi yang diatur secara manual, sehingga diasumsikan masing-masing wadah memperoleh pasokan udara yang relatif sama. Penggantian air pemeliharaan dilakukan setiap minggu sebanyak $25 \%$ dari volume total. Pada kelompok perlakuan, sumber air baru yang digunakan telah mengandung larutan ekstrak daun sambiloto pada dosis yang disesuaikan dengan masing-masing perlakuan. Pada masing-masing kelompok perlakuan, minimal sebanyak satu wadah (acak) dilengkapi dengan termometer minimum-maximum yang diukur setiap 24 jam. Suhu air pemeliharaan selama berlangsungnya percobaan dipertahankan agar selalu pada kisaran $24^{\circ} \mathrm{C}-28^{\circ} \mathrm{C}$. Pengaturan suhu air pada kisaran tersebut dilakukan dengan cara memasukkan es (terbungkus plastik) pada saat suhu air mulai pada posisi $27^{\circ} \mathrm{C}$, dan biasanya terjadi pada siang hari antara pukul 12.00-14.00.

Disain percobaan yang digunakan adalah Rancangan Acak Lengkap (RAL) yang terdiri atas lima faktor sebagai perlakuan. Perlakuan yang diterapkan adalah pemberian ekstrak daun sambiloto kedalam media pemeliharaan pada dosis yang berbeda, yaitu:

$\mathrm{A}$ : media pemeliharaan mengandung $100 \mathrm{mg} /$ L ekstrak daun sambiloto

B: media pemeliharaan mengandung $200 \mathrm{mg} /$ L ekstrak daun sambiloto

C: media pemeliharaan mengandung $300 \mathrm{mg} /$ L ekstrak daun sambiloto

D: media pemeliharaan mengandung $400 \mathrm{mg} /$ L ekstrak daun sambiloto

E: tanpa pemberian ekstrak daun sambiloto sebagai kontrol

Konsentrasi obat selama penelitian dipertahankan dengan cara mengganti media air baru yang telah mengandung obat dengan dosis seperti tersebut diatas. Masing-masing perlakukan dilakukan pengulangan sebanyak tiga kali.

Pengamatan dilakukan terhadap tingkah laku, gejala klinis, dan mortalitas ikan uji yang dilakukan setiap hari (pagi dan sore) hingga akhir percobaan yang berlangsung selama 21 hari. Selain itu, pengambilan sampel untuk diagnosis dengan PCR secara acak sebanyak 3 ekor dari masing-masing perlakuan (1 ekor per 
wadah) juga dilakukan setiap minggu hingga akhir pengamatan. Pada saat pengambilan sampel ikan, dilakukan pula analisis beberapa parameter kualitas air $\mathrm{pH}$, nitrit, nitrat, amonia, total bahan organik terlarut, alkalinitas, dan kesadahan), sedangkan fluktuasi suhu air (minimum-maksimum) diamati setiap hari.

\section{HASIL DAN BAHASAN}

\section{Hasil}

Ekstraksi dari tiga bentuk sediaan daun sambiloto, yaitu: basah, kering, dan bubuk menunjukkan bahwa ekstrak dari bentuk sediaan basah memiliki efektivitas anti mikrobial yang lebih rendah bila dibandingkan dengan dua bentuk lainnya. Namun tidak ada perbedaan efektivitas antara hasil ekstraksi dari bentuk sediaan kering dengan bubuk. Dari hasil uji pendahuluan ini, maka pengujian selanjutnya ditentukan hanya menggunakan ekstrak dari bentuk sediaan kering. Hal ini didasarkan pada pertimbangan kemudahan penyediaan serta aplikasinya di lapangan.

Hasil uji potensi anti mikrobial ekstrak daun sambiloto secara in vitro dengan metode difusi agar terhadap bakteri model yaitu $A$. hydrophila menunjukkan bahwa sambiloto memiliki efek anti mikrobial yang cukup baik seperti terlihat pada Tabel 1. Meskipun target patogen yang hendak dikendalikan pada percobaan ini bukan dari golongan bakteri, namun dari hasil uji in vitro ini digunakan sebagai referensi penentuan dosis yang diterapkan pada percobaan ini. Gambar 1 menunjukkan daun sambiloto basah sampai dikeringkan serta pengujian potensi antimikrobial ekstrak daun sambiloto pada konsentrasi $3.000 \mathrm{mg} / \mathrm{L}$.
Pengujian efek racun ekstrak daun sambiloto melalui uji bioassay terhadap ikan mas ukuran antara 10-15 g/ekor menunjukkan bahwa $\mathrm{LD}_{50}$ selama 72 jam diperoleh pada konsentrasi antara 3.000-5.000 mg/L. Berdasarkan hasil uji tersebut, maka penentuan dosis perlakuan antara 100-400 $\mathrm{mg} / \mathrm{L}$ dianggap sangat aman bagi hewan uji.

Populasi ikan mas yang digunakan pada percobaan ini telah memenuhi "definisi kasus KHV" yang dikembangkan oleh Taukhid et al. (2005) yang didasarkan pada tiga indikator yang memiliki konsistensi, yaitu: indikator pertama KHV hanya menginfeksi Cyprinus carpio, indikator kedua adalah insang ikan berwarna pucat, terdapat bercak putih (white patch) selanjutnya menjadi rusak, geripis pada ujung lamella dan akhirnya membusuk (Gambar 2a), dan indikator ketiga terjadi kematian massal dalam waktu yang relatif singkat (Gambar 2b). Hasil konfirmasi secara laboratoris melalui uji PCR menunjukkan hasil positif, dengan demikian, populasi ikan mas uji secara definitif telah terinfeksi KHV sehingga tidak diperlukan lagi proses kohabitasi untuk menginduksi infeksi secara buatan.

Kematian ikan mas uji terjadi pada seluruh kelompok perlakuan dan berlangsung sejak hari ke-1 hingga akhir percobaan. Tingkat kematian yang cukup tinggi umumnya berlangsung pada hari ke-1 hingga ke-7, kemudian berangsur menurun pada minggu ke2 hingga akhir percobaan.

Pada tabel tersebut terlihat bahwa rataan persentase sintasan tertinggi diperoleh pada kelompok perlakuan D (ekstrak daun sambiloto pada konsentrasi $400 \mathrm{mg} / \mathrm{L}$ ), yaitu sebesar 42,22\%; kemudian diikuti oleh perlakuan C, B, $E$, dan A masing-masing sebesar 31,67\%;

Tabel 1. Rataan diameter zona hambat ekstrak daun sambiloto terhadap biakan bakteri Aeromonas hydrophila

Table 1. Mean of inhibition zone of sambiloto extract against Aeromonas hydrophila

\begin{tabular}{cc}
\hline $\begin{array}{c}\text { Konsent rasi } \\
\text { Concentration } \\
(\mathbf{m g} / \mathrm{L})\end{array}$ & $\begin{array}{c}\text { Diameter zona hambat } \\
\text { Inhibition diameter zone } \\
(\mathbf{m m})\end{array}$ \\
\hline 100 & 10.42 \\
300 & 13.46 \\
500 & 11.74 \\
1,000 & 12.66 \\
3,000 & 14.34 \\
\hline
\end{tabular}




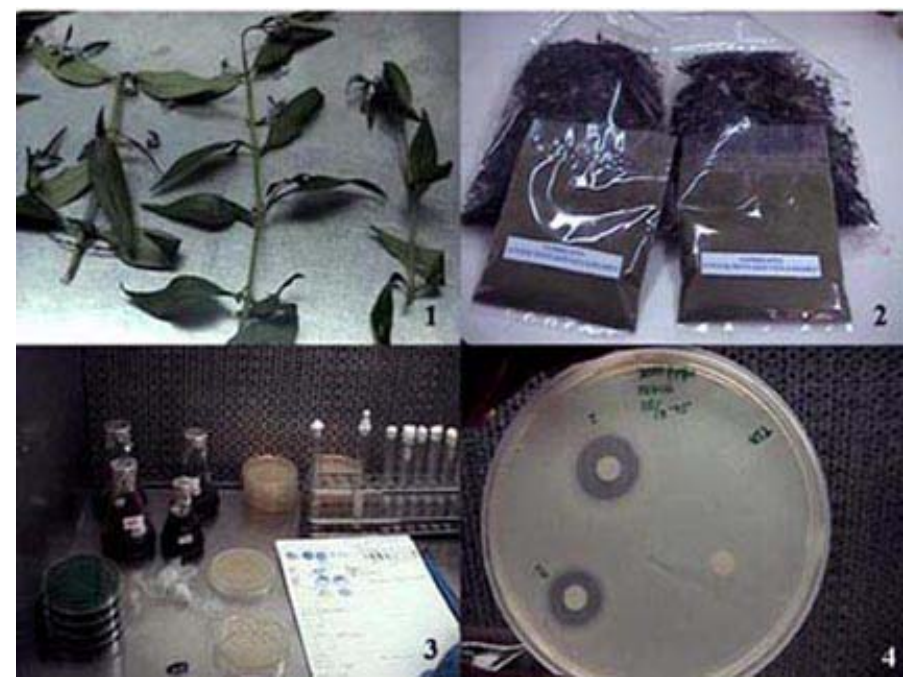

Gambar 1. Daun sambiloto segar, daun sambiloto yang telah dikeringkan (simplisia) dan yang telah diproses dalam sediaan bubuk, proses pengujian potensi antimikrobial ekstrak daun sambiloto terhadap bakteri Aeromonas hydrophila, dan potensi antimikrobial ekstrak daun sambiloto terhadap bakteri model yang ditunjukkan dengan adanya zona hambat

Figure 1. Sambiloto leaf, dried, and powdered of sambiloto leaf, preparation of anti microbial test, and result of anti microbial property of sambiloto leaf extract

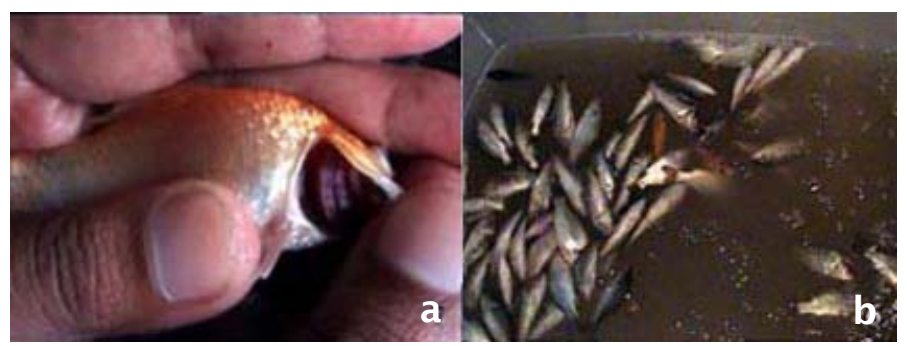

Gambar 2. (a) Salah satu gejala klinis ikan mas yang terinfeksi KHV dan (b) populasi ikan mas yang mengalami kematian massal akibat infeksi KHV

Figure 2. (a) Clinical sign of KHV infection on the gill and (b) mass mortality of common carp population due to KHV infection

$16,12 \% ; 12,78 \%$; dan $11,12 \%$. Gambaran yang lebih jelas dapat dilihat pada Tabel 2 .

Analisis statistik terhadap persentase sintasan kumulatif menunjukkan bahwa terdapat perbedaan yang nyata pada selang kepercayaan $95 \%(\mathrm{P}<0,05)$ antar kelompok perlakuan.

Uji PCR terhadap sampel ikan mas yang dilakukan setiap minggu menunjukkan hasil sebagai berikut: (1) Sesaat sebelum dimasukkan ke masing-masing wadah percoba- an, populasi ikan mas uji menunjukkan positif terinfeksi KHV (Gambar 3a); (2) pada sampling minggu ke-1 seluruh kelompok perlakuan beserta kontrol menunjukkan hasil negatif KHV (Gambar 3b); (3) pada sampling minggu ke-2 seluruh kelompok perlakuan beserta kontrol menunjukkan hasil positif KHV (Gambar 3c); dan (4) pada sampling minggu ke-3 (akhir percobaan), kecuali kelompok perlakuan D negatif KHV; sedangkan kelompok lainnya termasuk kontrol menunjukkan positif KHV (Gambar 3d). 
Tabel 2. Rataan persentase sintasan ikan mas (Cyprinus carpio) positif terinfeksi Koi Herpes Virus (KHV) yang dipelihara selama 21 hari dalam media yang mengandung ekstrak daun sambiloto (Andrographis paniculata)

Table 2. Percentage of survival rate of diseased common carp (Cyprinus carpio) during experimental period in the different concentration of sambiloto leaf extract (Andrographis paniculata)

\begin{tabular}{lc}
\hline $\begin{array}{c}\text { Perlakuan } \\
\text { Treatment }\end{array}$ & $\begin{array}{c}\text { Sintasan } \\
\text { Survival rate (\%) }\end{array}$ \\
\hline $\mathrm{A}(100 \mathrm{mg} / \mathrm{L})$ & 11.12 \\
$\mathrm{~B}(200 \mathrm{mg} / \mathrm{L})$ & 16.12 \\
$\mathrm{C}(300 \mathrm{mg} / \mathrm{L})$ & 31.67 \\
$\mathrm{D}(400 \mathrm{mg} / \mathrm{L})$ & 42.22 \\
$\mathrm{E}($ kontrol $)$ & 12.78 \\
\hline
\end{tabular}

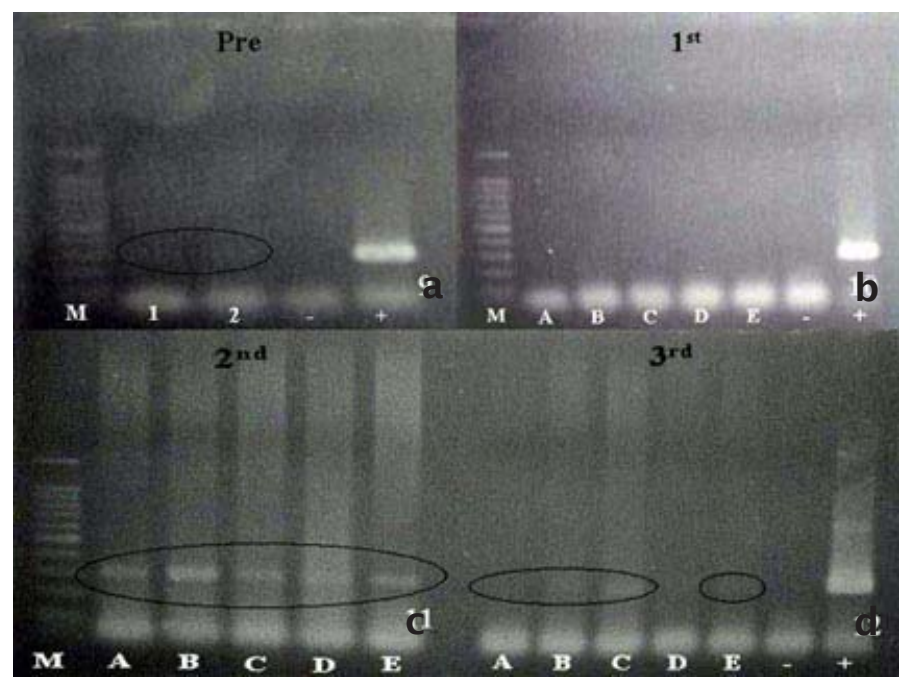

Gambar 3. (a) Hasil uji polymerase chain reaction (PCR) terhadap populasi ikan mas sesaat sebelum dimasukkan ke dalam wadah percobaan: kedua reaksi menunjukkan (+) terinfeksi Koi Herpes Virus (KHV), (b) sampling I: seluruh perlakuan menunjukkan (-) KHV, (c) sampling II: seluruh perlakuan menunjukkan (+) KHV, dan (d) sampling III: A, B, C, dan E menunjukkan (+) KHV sedangkan D menunjukkan (-) KHV

Figure 3. (a) Polymerase Chain Reaction (PCR) product of fish test before used: both of reaction are show (+) infected by Koi Herpesvirus (KHV), (b) first sampling: all of group show (-) KHV infection, (c) second sampling: all of group show (+) KHV infection, and (d) third sampling: $A, B, C$, and $E$ are show (+) KHV infection, meanwhile $D$ is (-) KHV infection

\section{Bahasan}

Daun sambiloto memiliki efek anti mikrobial yang cukup baik, hal ini terlihat dari adanya zona hambat terhadap pertumbuhan bakteri yang digunakan sebagai model pada percobaan ini, yaitu $A$. hydrophila. Komponen utama yang terkandung dalam sambiloto adalah andrographolid, zat ini memiliki multiefek farmakologis antara lain: mampu menghambat pertumbuhan sel kanker payudara, prostat, dan berkhasiat sebagai hepatoprotektor (melindungi sel hati dari zat toksik). Selain itu, tumbuhan yang pahit ini juga berperan sebagai imunostimulator (pemicu induksi kekebalan spesifik dan non-spesifik). Berdasarkan zat 
aktif yang dikandungnya, sambiloto memiliki beberapa efek farmakologis, antara lain: sebagai anti radang (anti inflamasi), anti infeksi yang disebabkan oleh mikroorganisme, merangsang daya tahan sel (fagositosis) darah putih sehingga efektif untuk melawan infeksi, anti bakteri, penghilang rasa nyeri (analgesik), pereda demam (anti piretik), penghilang panas dalam, anti racun (detoksikasi), dan berfungsi sebagai hepatoprotektor (Prapanza \& Marianto, 2003). Selanjutnya dikatakan bahwa berkat efek farmakologisnya yang cukup banyak, sambiloto dapat digunakan untuk menyembuhkan berbagai jenis penyakit, mulai dari yang dianggap ringan (influenza) hingga yang berat (kanker dan HIV). Bahkan di Skandinavia, sambiloto merupakan herbal teratas untuk mengatasi penyakit-penyakit infeksi. Di Cina, sambiloto sering digunakan untuk berbagai pengobatan, antara lain untuk menghilangkan racun ular, pneumonia (radang paru), infeksi tenggorokan, dan lain-lain.

Hingga kini belum diketahui bukti ilmiah yang mendukung bahwa sambiloto dapat menyembuhkan penyakit yang diakibatkan oleh infeksi virus. Demikian pula penggunaan sambiloto terhadap infeksi virus pada ikan. Hal yang mendasari penggunaan sambiloto pada riset ini adalah kenyataan bahwa sebagian besar infeksi KHV pada ikan mas selalu diikuti oleh infeksi sekunder oleh bakteri, dan kondisi ini sudah tentu akan memperparah kondisi kesehatan ikan yang akhirnya berakibat pada kematian.

Potensi anti mikrobial yang dimiliki sambiloto merupakan alternatif upaya pengendalian infeksi sekunder oleh bakteri yang lebih prospektif dan ramah lingkungan. Taukhid et al. (2005) menyatakan bahwa penggunaan obat/antibiotik yang dilakukan pembudi daya ikan mas untuk pengendalian kasus penyakit KHV hanyalah salah satu upaya untuk menekan infeksi sekunder oleh patogen lain seperti bakteri, jamur atau parasit; namun tidak berperan untuk mengobati infeksi KHV. Meskipun upaya pengobatan tidak selalu menolong kesembuhan pada populasi ikan yang sudah terinfeksi pada level berat, namun terhadap populasi ikan yang belum memperlihatkan gejala klinis \& kematian yang serius; penggunaan bahan kimia/antibiotik umumnya dapat mengurangi resiko kematian. Tambahan lagi bahwa efek racun ekstrak daun sambiloto terhadap ikan mas, baru akan terjadi pada konsentrasi yang sangat tinggi yaitu antara 3.000-5.000 mg/L; sehingga secara umum dianggap sangat aman bagi ikan yang hendak diobati.

Sambiloto juga berfungsi sebagai imunostimulan (Prapanza \& Marianto, 2003), yang berarti dapat menginduksi kekebalan nonspesifik serta memfasilitasi pembentukan pertahanan spesifik. Secara umum sudah terbukti bahwa penggunaan berbagai jenis imunostimulan sangat membantu dalam meningkatkan status kesehatan ikan, termasuk terhadap infeksi KHV.

Kematian yang terjadi pada seluruh kelompok perlakuan mengindikasikan bahwa KHV merupakan penyakit yang ganas. Tingginya tingkat kematian pada minggu pertama dibandingkan dengan minggu-minggu berikutnya, sangat mungkin terkait dengan masa inkubasi dari infeksi virus tersebut. Menurut OATA (2001), KHV merupakan penyakit viral pada ikan mas dan koi (Cyprinus carpio) yang sangat menular, mengakibatkan morbiditas dan mortalitas antara $80 \%-100 \%$ dari populasi ikan, dengan masa inkubasi antara 1-14 hari. Adanya perbedaan rataan persentase sintasan yang signifikan antar kelompok perlakuan menunjukkan bahwa terdapat pengaruh positif akibat pemberian ekstrak sambiloto pada media pemeliharaan ikan uji. Apabila dibandingkan dengan kelompok kontrol, maka konsentrasi ekstrak sambiloto yang memberikan nilai positif secara linier didapatkan mulai dari konsentrasi 200 $\mathrm{mg} / \mathrm{L}$, kemudian pada $300 \mathrm{mg} / \mathrm{L}$, dan efek terbaik diperoleh pada $400 \mathrm{mg} / \mathrm{L}$. Sedangkan nilai rataan persentase sintasan pada konsentrasi $100 \mathrm{mg} / \mathrm{L}$ memberikan hasil yang lebih rendah dibandingkan dengan kelompok kontrol, meskipun secara statistik tidak ada perbedaan yang signifikan.

Nilai rataan sintasan yang lebih tinggi pada kelompok perlakuan membuktikan bahwa ekstrak daun sambiloto di atas $200 \mathrm{mg} / \mathrm{L}$ dapat berfungsi sebagai materi biologis yang mampu mereduksi kasus KHV pada ikan mas, meskipun mekanisme dari kondisi tersebut belum diketahui secara pasti. Kuat dugaan bahwa fungsi antimikrobial serta imunostimulan dari ekstrak sambiloto bekerja secara sinergis, hal ini terlihat bahwa semakin tinggi konsentrasi; hasil yang diperoleh juga semakin baik.

Hasil diagnosis KHV dengan teknik PCR terhadap sampel ikan mas yang dilakukan setiap minggu menunjukkan hasil yang fenomenal, terutama pada sampling minggu ke1. Kondisi seperti ini sangat mungkin terjadi, 
bahwa diagnosis PCR single step terhadap KHV terkadang belum memberikan hasil yang akurat bagi sampel sub-klinis. Dari hasil diagnosis PCR ini juga mengindikasikan bahwa ikan mas yang tetap hidup setelah terinfeksi KHV, ternyata di dalam tubuhnya masih mengandung KHV. Sehingga dari fenomena ikan survivor setelah terinfeksi KHV dapat dikelompokkan menjadi 3 kategori. Pertama, ikan survivor dari kasus KHV menjadi populasi yang kebal (resisten), bebas virus di dalam tubuhnya dan besar kemungkinan apabila terjadi wabah serupa, populasi tersebut akan tetap selamat karena memiliki antibodi spesifik hingga level protektif. Kedua, ikan survivor menjadi relatif kebal namun masih membawa (carriers) virus di dalam tubuhnya, dan sangat berpotensi untuk menularkannya ke populasi lain yang masih bebas tanpa mematikan dirinya. Ketiga, survivor menjadi pembawa dan tetap rentan terhadap KHV apabila ada pemicu yang mengakibatkan munculnya penyakit tersebut.

\section{KESIMPULAN DAN SARAN}

\section{Kesimpulan}

Ekstrak daun sambiloto memiliki potensi anti mikrobial yang cukup baik pada dosis di atas $100 \mathrm{mg} / \mathrm{L}$; dan pada dosis di atas 200 $\mathrm{mg} / \mathrm{L}$ memiliki fungsi untuk mengendalikan penyakit KHV pada ikan mas.

Teknik ekstraksi daun sambiloto yang masih memberikan hasil cukup baik, dapat dilakukan melalui proses perebusan.

Ikan mas yang mampu bertahan hidup dari infeksi KHV diduga masih mengandung virion KHV di dalam tubuhnya, hal ini terlihat dari hasil diagnosis PCR terhadap kelompok ikan survivor yang ternyata masih positif KHV.

\section{Saran}

Perlu dikembangkan teknik diagnosis penyakit KHV dengan double step PCR, dengan harapan mampu mendeteksi infeksi KHV pada kondisi sub-klinis.

Perlu dieksplorasi pemanfaatan herbal therapy bagi upaya pengendalian infeksi sekunder pada kasus KHV, serta materi biologis lainnya sebagai imunostimulan terhadap KHV.

\section{UCAPAN TERIMA KASIH}

Riset ini dibiayai dari Anggaran Balai Riset Perikanan Budidaya Air Tawar, DIPA 2005. Penulis mengucapkan terima kasih kepada Sdr. Bambang Priadi, Mikdarullah, Edy Farid, dan Ati Puspitasari yang telah membantu pelaksanaan kegiatan ini baik di laboratorium maupun di lapangan.

\section{DAFTAR PUSTAKA}

Anonim. 2004. Statistik Perikanan Budidaya Indonesia Tahun 2002. Jakarta. 127 pp.

Gray, W.L., L. Mullis, S.E. LaPatra, J.M. Groff, and A. Goodwin. 2002. Detection of koi herpesvirus DNA in tissues of infected fish. Journal of Fish Diseases. 25: 171-178.

Hedrick, R.P., O. Gilad, S. Yun, J.V. Spangenberg, G.D. Marty, R.W. Nordhausen, M.J. Kebus, H. Bercovier, and A. Eldar. 2000. A herpesvirus associated with mass mortality of juvenile and adult koi, a strain of common carp. Journal of Aquatic Animal Health. 12: 4457.

Ornamental Aquatic Trade Association (OATA). 2001. Koi Herpes Virus (KHV). OATA, Westbury, Wilts, UK. p. 4-33.

Ronen, A., A. Parelberg, J. Abramovitz, M. Hutoran, S. Tinman, I. Bejerano, M. Steinitz, and M. Kotler. 2003. Efficient vaccine against the virus causing a lethal disease in cultured Cyprinus carpio. Vaccine. 21 (32): 4,625--4.743.

Prapanza, I. dan L.A. Marianto. 2003. Khasiat dan Manfaat Sambiloto Raja Pahit Penakluk Aneka Penyakit. AgroMedia Pustaka, Jakarta. 60 pp.

Taukhid, A. Sunarto, I. Koesharyani, H. Supriyadi, dan L. Gardenia. 2005. Strategi pengendalian penyakit Koi Herpes Virus (KHV) pada ikan mas dan koi. Dalam H. Supriyadi dan B. Priono (Eds.). Strategi Pengelolaan dan Pengendalian Penyakit KHV. Pusat Riset Perikanan Budidaya, Jakarta. p. 41--60. 